\title{
A SYSTEM APPROACH TO SIMULATION OF INDIVIDUAL FOOD PRODUCTS
}

\author{
Andrey B. Lisitsyn, Irina M. Chernukha, Marina A. Nikitina* \\ V. M. Gorbatov Federal Research Center for Food Systems of Russian Academy of Sciences, Moscow, Russia
}

\begin{abstract}
Keywords: simulation of living systems, individual food product, system approach, protein cleavage
Abstract

There is no doubt that the further development in the field of nutrition is linked with personalization. Nutrition management with account for metabolism plays a key role in health strengthening and prevention of human diseases. The paper gives a review of studies associated with personalized nutrition. Personalized nutrition is inextricably linked with personalized food products. At present, however, mass production of personalized food products for individuals or small groups of people is unfeasible. The development of personalized food products requires both time and labor input, as well as multidisciplinary and profound knowledge in a wide spectrum of areas associated with biology, medicine, nutrition and food systems. Among the most important characteristics of modern science is the study of complex and super-complex organized objects such as the food system. These objects were studied previously but by the way of significant simplification of their structure. Investigation of objects with all variety and complexity of their organization requires not only new scientific ideas but also a new conceptual framework, new research methodology, new approaches to simulation of both products and physiological processes. In this study, the authors made an attempt to bring the theoretical view on an individual product closer to the complex task solution using the method of mathematical physiology. The intuitive conceptual model for a process of food design is shown with regard to the "health passport" of an individual, disease risk and gastrointestinal (GI) tract status. The differential equations of the concentration dynamics of protein, denatured protein and peptides in the human stomach are presented. The differential equations that describe the process of protein assimilation in the human stomach were solved in the simulation environment Simplex 3. The presented fragments of model realization show the possibility of virtual study on an effect of different indicators of the food nutritional value on the rate of digestion and the process of cleavage of complex components (proteins, fats and carbohydrates) to mono-structural elements depending on different state and influence factors.
\end{abstract}

Funding: The article was published as part of the research topic No. 0585-2019-0008 of the state assignment of the V. M. Gorbatov Federal Research Center for Food Systems of RAS.

\section{Introduction}

The idea of personalized medicine was presented for the first time by American biochemist Roger John Williams in the book "Biochemical Individuality: The Basis for the Genetotrophic Concept" [1] in 1956. In this book, R. J. Williams stressed the uniqueness of each person in terms of metabolism and requirements in nutritional microelements. Due to the "biochemical individuality", persons have their own nutrition requirements.

However, this idea was implemented only after human genome mapping in 2003 [2].

Nutrition management in chronic diet-related diseases can be improved based on data about the genome of a particular individual. To establish an interaction, the four-year Food4Me project (http://www.food4me.org/) financed by the European Commission was launched with the involvement of experts in the field of nutrition from different countries. The project envisaged individual recommendations on nutrition at three levels: 1) only a human diet; 2) a diet combined with the knowledge of human phenotype (measurable characteristics, such as height, weight, cholesterol level and so on); 3 ) a diet, phenotype and genotype (detection of the hereditary genetic identity of a person, for example, a gene variant linked with the weight gain). The European-wide study (more than 1500 adults from Germany, Greece, Ireland, the Netherlands, Poland, Spain and UK) showed that personalized recommendations on nutrition were more effective for improving dietary behavior than traditional recommendations for population.

The results were presented at the project's final conference "Personalised nutrition: paving a way to better public health?' in Brussels on February 26, 2015. The study demonstrates that remote collection of phenotypic data and data on food consumption through the Internet is possible and allows obtaining consistent and reliable data $[3,4,5]$.

It is worth emphasizing that personalized nutrition is inextricably linked with personalized food products. At present, mass production of personalized food products for individuals or small groups of people is unfeasible. Therefore, the development of personalized food products requires both time and labor input, as well as multidisciplinary and profound knowledge in a wide spectrum of areas associated with food products.

The fundamental trends that shape the world are analyzed and discussed in [6,7]. One of the megatrends is the availability of right personalized food products to prevent, mitigate diet-related diseases especially for vulnerable population groups including the elderly. At the same time, King et al. [7] 
believe that introduction of different types of microbiomes to cure people of certain diseases (personalized approach) will lead to food safety problems. Systematic research including the use of nutrigenomics, metabolomics and toxicogenomics is necessary to ensure safety of personalized products.

A process of designing personalized nutrition along the food chain is presented in [8] covering the following topics: 1) food raw materials and components; 2) food industry and gastronomy aspects; 3) digestion and microbiota; 4) food perception (Figure 1).

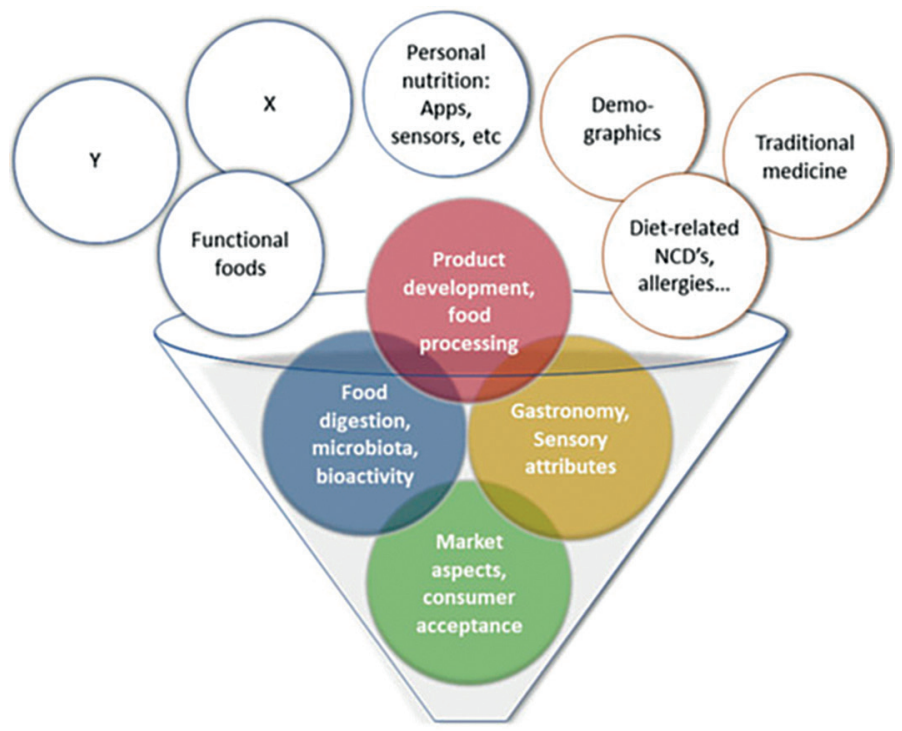

PERSONALISED FOOD

Figure 1. Individual approach to food [8]

The Biomolecula portal (https://biomolecula.ru) has the project "Science for life extension", which points out that developed countries have faced the consequences of irrational nutrition such as obesity and type 2 diabetes mellitus over the last years [9] (Figure 2). It was established that longevity and the development of "deadly three" - cardiovascular, neurodegenerative and oncological diseases - depend on a human diet [10].

Medical data show the interrelation between nutrition and the most prevalent non-communicable diseases. In 2019, the research results of the scientific team from the USA, Norway and Spain were published [11]. The scientists analyzed data on the health state of the population from 195 countries and territories for the period from 1990 to 2017. They identified 92 diagnoses that finally led to irreversible deterioration of physical or mental abilities of patients. Among them were cardiovascular diseases (13), chronic respiratory diseases (6), cancers (35), diabetes, chronic kidney diseases, injuries and neurodegenerative diseases as well as vision and hearing impairments.

Analysis showed that age-related diseases accounted for more than half of health problems in all adult population of the world; however, data differed between countries and senility began at a very different age (Figure 3 ).

According to the data of 2017, the lowest SDI was in the Republic of the Niger (0.19), Somali (0.23), Afghanistan (0.29). SDI was 0.79 in Russia, 0.77 in Belarus, 0.7 in

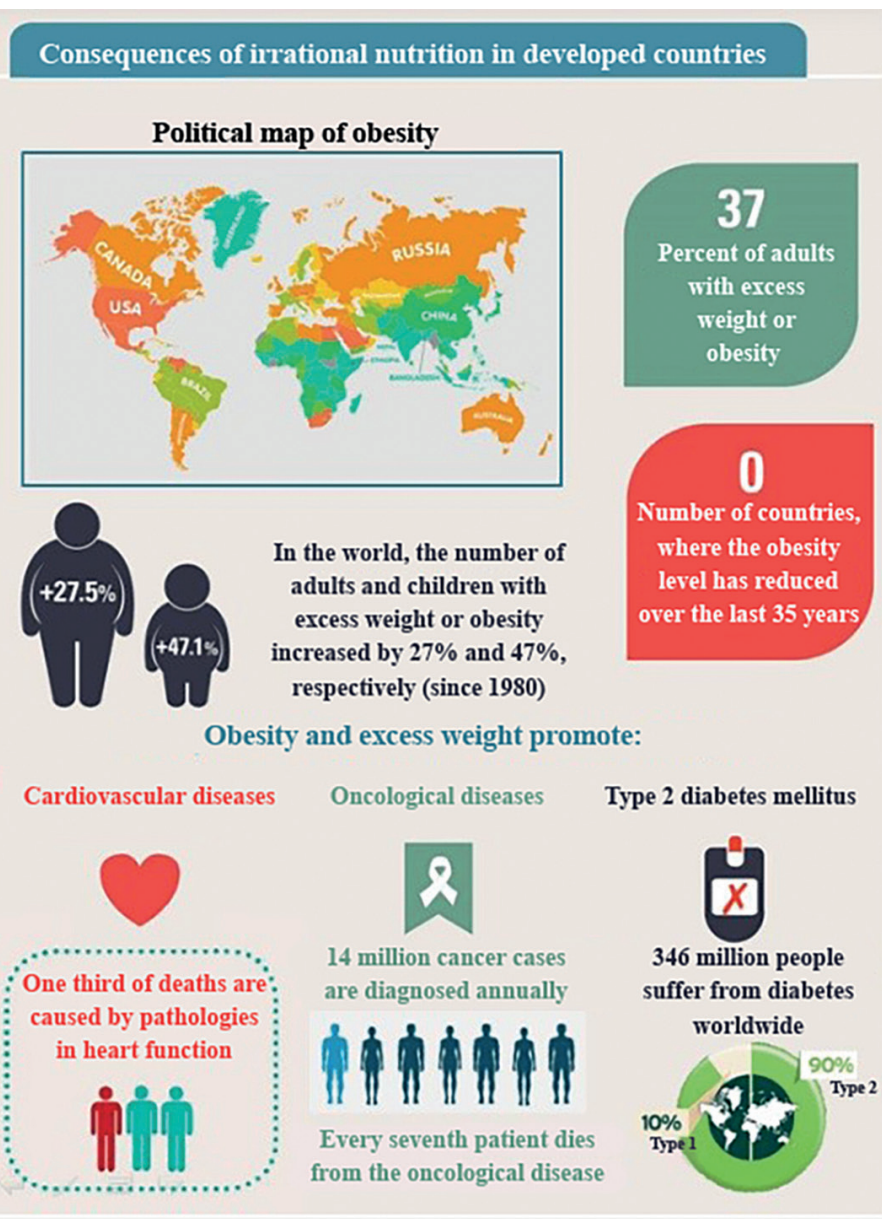

Figure 2. Consequences of unbalanced nutrition in developed countries: prevalence of obesity and type 2 diabetes mellitus. The excess weight and "western diet" contribute to the development of cardiovascular and oncological diseases, type 2 diabetes mellitus [biomolecula.ru]

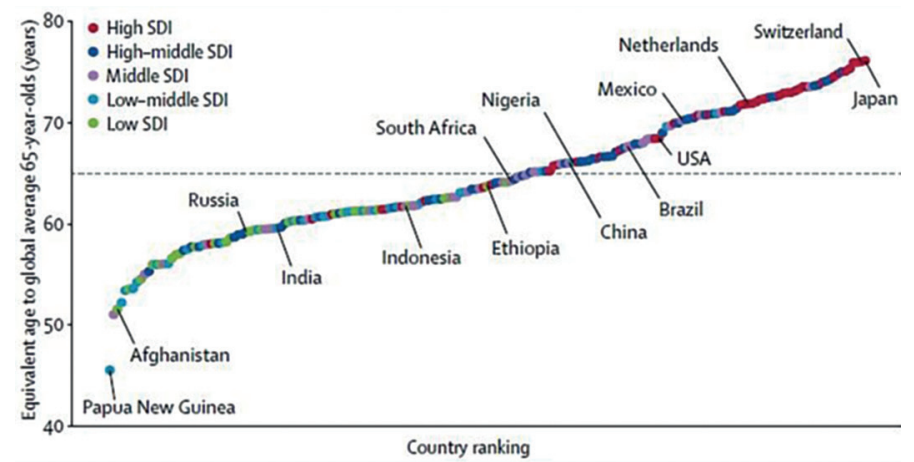

Figure 3: Comparison of the equivalent ages with global average index (65 years) across countries in 2017 [11]. SDI (Socio-demographic Index) - a summary measure of a degree of a country or region development expressed in values from 0 to 1 [12]

Armenia, 0.7 in Azerbaijan, 0.69 in Georgia, 0.74 in Kazakhstan, 0.6 in Kirgizstan, 0.62 in Uzbekistan. The highest SDI was in Denmark, Luxemburg (0.92), the Netherlands, Norway (0.91).

It is noted that although in developing countries (with low socio-demographic Index - SDI) longevity is considerably lower than in the developed ones, people still experience the burden of senility and accumulate age-related diseases. It just happens significantly earlier.

Chang A. et al. from the University of Washington Seattle have noticed that these incomparable results indicate that 
an increase in longevity can be regarded in the old age both as additional opportunities and as a threat to well-being of a society in general depending on the age when the real age-related health problems arose in individuals and not on their actual age.

According to Ludwig von Bertalanffy [13], the system approach is an approach, in which any system (object) is regarded as an assembly of interrelated elements (components) having the output (target), input (resources), communication with the external environment and feedback. This is the most complex approach.

Among the most important peculiarities of modern science is the study (examination) of complex and super-complex organized objects. These objects were studied previously but by the way of significant simplification of their structure. Investigation of objects with all variety and complexity of their organization requires not only new scientific ideas but also a new conceptual framework, new research methodology [14].

The main advantage of simulation modeling compared to analytical is a possibility to solve more complex tasks. Simulation models allow quite easy consideration of factors such as the presence of discrete and continuous elements, non-linear characteristics of system elements, multiple random impacts and others, which often create difficulties in analytical investigations. At present, simulation modeling is the most effective method for investigation of complex systems and often is the only feasible method for obtaining information about system behavior especially at the stage of its design $[14,15,16,17,18]$.

It should be mentioned that today an opportunity has arisen for the development and wider use of mathematical and information technologies and models in description of biological processes in particular linked with food production and consumption.

The authors of this paper propose using the system approach in simulation modeling of the development of individual food products with regard to the human "health passport", disease risk and gastrointestinal tract status.

The aim of the work is to use the system approach in the development of individual food products with detailing nutrient digestion in the human body.

\section{Methodology of the research}

The simulation modeling method enables solving tasks of complex system analysis including the tasks of assessing system structure variants, effectiveness of different algorithms of system management, effects of changes in different system parameters. Simulation modeling can also be used as the basis for structural, algorithmic and parametric synthesis of complex systems when it is necessary to create a system with given characteristics upon certain restrictions, which is optimal by several criteria of effectiveness assessment [14].

Simulation modeling was carried out in the program environment Simplex3 (http://www.simplex3.net/) $[19,20]$.

\section{Results}

After human health screening and obtaining their "health passport", it is necessary to develop food products having regard to nutrient digestibility. To this end, it is necessary to formalize (translate to the mathematical language) processes occurring in the gastrointestinal tract using methods for modeling of living systems, including mathematical physiology methods [21,22].

The human gastrointestinal tract can be considered a natural biochemical reactor that ensures mechanical, thermal, enzymatic and microbiological processing of nutrients by their main components (proteins, fats, carbohydrates). The digestive process, therefore, consists in hydrolysis of nutrients (substrates) under the action of enzymes along the gastrointestinal tract and can be described by the system of Michaelis-Menten substrateenzymatic reactions [23]. At the same time, it is necessary to take into account peculiarities of the human GI tract, first of all, $\mathrm{pH}$, the presence of pathologies (for example, ulcer disease), food component composition, consistency and temperature.

We presented the structural-parametric model of the GI tract and structural - parametric model of a product separately in $[24,25,26]$. In the system approach, they will be examined as components of a single model.

A model of an individual food product requires not only consideration for food design according to indices of the nutritional and biological value but also the understanding of what part of nutrients in a food product will be assimilated by certain individuals with regard to their physiological characteristics. For this purpose, mathematical models of biological processes and equations of mathematical physics are used as a rule.

We will show the possibilities of simulation modeling by the example of protein cleavage and assimilation. To this end, at the beginning, we will describe multiple subsystems, organs, variables and links between them in the form of graphic presentation - the IDEF0 scheme (Figure 4).

Changes in the variables of the state of the certain GI tract segments can be described in finite differences by a sum of influencing components in the system of algebraic equations:

$$
\Delta X_{i}=\sum_{j}^{N} w_{i j} \cdot f_{i j} \cdot \Delta X_{j} ; i=1.20
$$

where $f_{i j}$ is the influence function of the $j^{\text {th }}$ influencing factor (enzymes, chemical substances of the influencing environment, mechanisms of substance transport) on the $i^{\text {th }}$ parameter of the GI tract state; $w_{i j}$ is the sign function of the direction of the influence of the $j^{\text {th }}$ factor on the $i^{\text {th }}$, stimulating $(+)$ or re$\operatorname{tarding}(-)$.

Dynamics of the biochemical reactions of the enzymatic type as well as the biochemical and biomechanical processes of substance transport along the GI tract are described in [27] by the system of ordinary differential equations: 


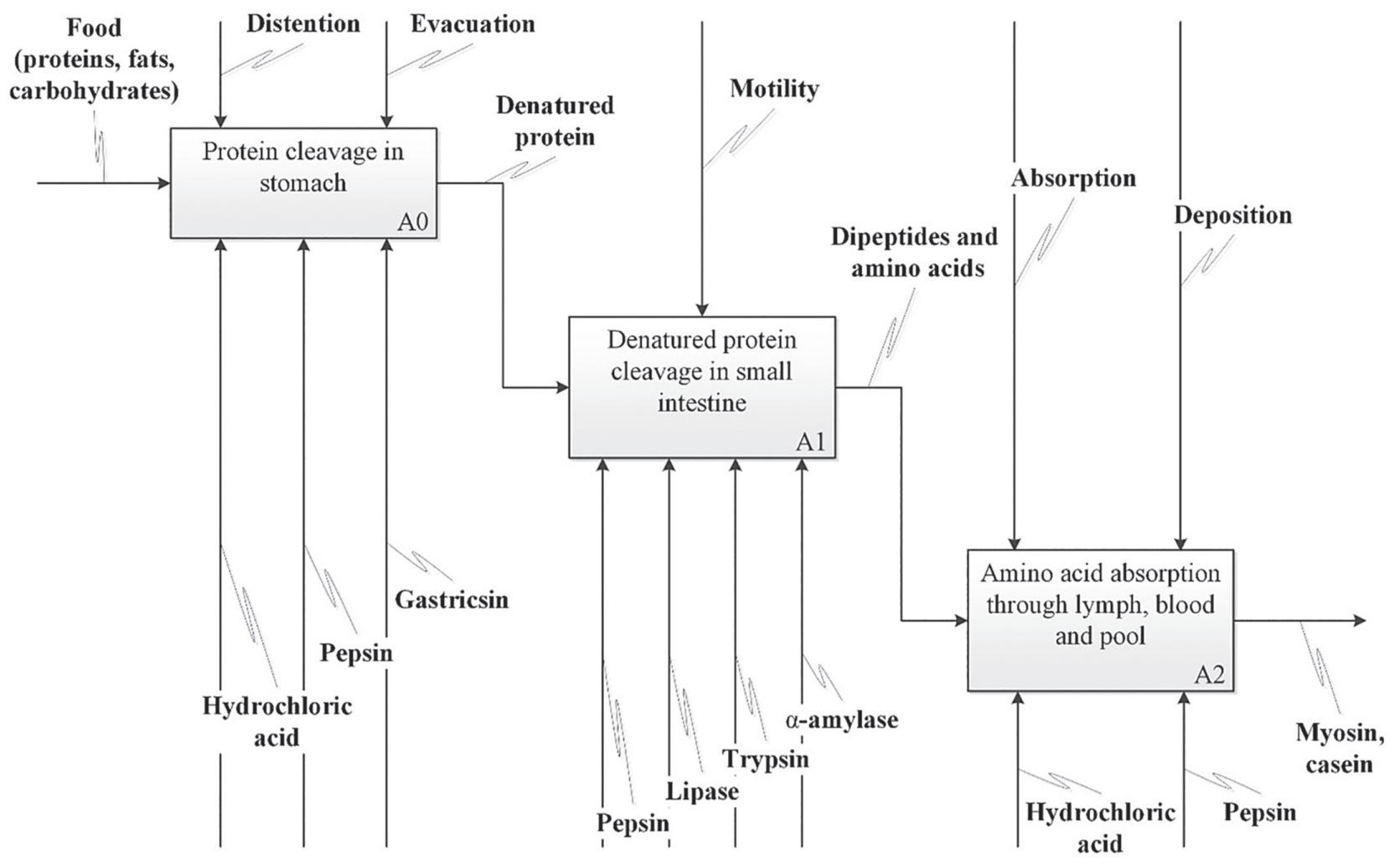

Figure 4. The scheme of protein cleavage; a blood pool - an organ or tissue with an ability to accumulate in its vessels a significant amount of blood, which can be used by the body when necessary (for example, liver, spleen, skin blood vessels and so on)

$$
\frac{d X_{i}}{d t}=r \sum_{l=1}^{n_{i}} \sum_{j=1}^{23} \frac{w_{i j} \alpha_{j l} X_{l} Y_{j}}{\left(1+\beta_{j l} X_{l}\right)} ; i=\overline{1.20}
$$

where $X, Y$ are variables of the system state and influencing factors of the biochemical environment, respectively; $\alpha_{j l}$ are coefficients of the intensity of the $j^{\text {th }}$ influence of enzymes and transport mechanisms on the $i^{\text {th }}$ parameter of the state; $\beta_{j l}$ are coefficients of chemical reactions or substance transport; $r$ are scale coefficients of rates of changes in variables in different GI tract segments.

Table 1 presents the used variables of the digestive system state and table 2 shows the factors of the biochemical environment of the GI tract and transport mechanisms.

Table 1. An example of description of food components transformed in the digestive process

\begin{tabular}{|c|c|c|c|}
\hline $\begin{array}{l}\text { है } \\
\text { है }\end{array}$ & $\begin{array}{c}\text { Product components } \\
\text { determining digestive system } \\
\text { state }\end{array}$ & $\begin{array}{l}\text { है } \\
\text { हो } \\
\text { के }\end{array}$ & $\begin{array}{l}\text { Product components } \\
\text { determining digestive } \\
\text { system state }\end{array}$ \\
\hline \multicolumn{2}{|c|}{ In stomach } & \multicolumn{2}{|c|}{ In small intestine } \\
\hline$x_{1}$ & Proteins & $x_{6}$ & Denatured proteins \\
\hline$x_{2}$ & Fats (triglycerides) & $x_{7}$ & Peptides \\
\hline$x_{3}$ & Carbohydrates (polysaccharides) & $x_{8}$ & $\begin{array}{l}\text { Dipeptides and amino } \\
\text { acids }\end{array}$ \\
\hline$x_{4}$ & Denatured proteins & $x_{9}$ & Fats (triglycerides) \\
\hline$x_{5}$ & Peptides & $x_{10}$ & Emulsified fats \\
\hline \multicolumn{2}{|c|}{ In blood, lymph and pool } & $x_{11}$ & \\
\hline$x_{17}$ & Amino acids & $x_{12}$ & Fatty acids \\
\hline$x_{18}$ & Fatty acids & $x_{13}$ & $\begin{array}{l}\text { Carbohydrates } \\
\text { (polysaccharides) }\end{array}$ \\
\hline$x_{19}$ & Triglycerides & $x_{14}$ & oligosaccharides \\
\hline \multirow[t]{2}{*}{$x_{20}$} & Glucose & $x_{15}$ & Disaccharides \\
\hline & & $x_{16}$ & Glucose \\
\hline
\end{tabular}

Table 2. An example of analyzed factors of the GI tract environment

\begin{tabular}{|c|l|}
\hline Symbols & \multicolumn{1}{|c}{ Factors of the GI tract biochemical environment } \\
\hline$y_{1}$ & Hydrochloric acid \\
\hline$y_{2}$ & Pepsin(ogens) \\
$y_{3}$ & Bicarbonates of Brunner's glands \\
\hline$y_{4}$ & Bicarbonates of duodenum \\
\hline$y_{5}$ & Bicarbonates of pancreatic juice \\
\hline$y_{6}$ & Bile secretion (outflow to duodenum) \\
\hline$y_{7}$ & Enterokinase \\
\hline$y_{8}$ & Trypsinogen \\
\hline$y_{9}$ & Proteolytic enzymes of gastric juice \\
\hline$y_{10}$ & Peptidase \\
\hline$y_{11}$ & Dipeptidase \\
\hline$y_{12}$ & Lipase \\
\hline$y_{13}$ & Monoglyceride lipase \\
\hline$y_{14}$ & a-Amylase \\
\hline$y_{15}$ & Oligosaccharidase \\
\hline$y_{16}$ & Dissacharidase \\
\hline$y_{17}$ & Electrolytes in intestine \\
\hline$y_{18}$ & Ca ${ }^{++}$ \\
\hline$y_{19}$ & Gastric distention \\
\hline$y_{20}$ & Gastric evacuation \\
\hline$y_{21}$ & Intestinal motility \\
\hline$y_{23}$ & Absorption \\
\hline
\end{tabular}


In relation to the symbols (Table 1 and Table 2) and IDEF0 scheme, equation (2):

- for dynamics of the concentration of entered proteins $\left(x_{1}\right)$ in the stomach with regard to the factors of protein denaturation by hydrochloric acid $\left(y_{1}\right)$, gastric distention $\left(y_{19}\right)$ and evacuation $\left(y_{20}\right)$ is described in the expanded form by the following differential equation:

$$
\frac{d x_{1}}{d t}=x_{1}-\frac{\alpha_{1.19} x_{1}}{1+\beta_{1.19} x_{1}} y_{19}-\frac{\alpha_{1.1} x_{1}}{1+\beta_{1.1} x_{1}} y_{1}-\frac{\alpha_{1.20} x_{1}}{1+\beta_{1.20} x_{1}} y_{20}
$$

- for dynamics of the concentration of denatured protein in the stomach as a result of an impact of hydrochloric acid $\left(y_{1}\right)$ on entered protein $\left(x_{1}\right)$, reduction of the concentration of denatured protein $\left(x_{4}\right)$ due to an impact of pepsin $\left(y_{2}\right)$ and partial evacuation into small intestine $\left(y_{20}\right)$ has the form:

$$
\frac{d x_{4}}{d t}=\frac{\alpha_{1.1} x_{1}}{1+\beta_{1.1} x_{1}} y_{1}-\frac{\alpha_{2.4} x_{4}}{1+\beta_{2.4} x_{4}} y_{2}-\frac{\alpha_{20.4} x_{4}}{1+\beta_{20.4} x_{4}} y_{20}
$$

- for dynamics of the peptide $\left(x_{5}\right)$ concentration in the stomach reflects their accumulation upon cleavage of denatured protein $\left(x_{4}\right)$ by pepsin $\left(y_{2}\right)$ and reduction as a result of the further evacuation $\left(y_{20}\right)$

$$
\frac{d x_{5}}{d t}=\frac{\alpha_{2.4} x_{4}}{1+\beta_{2.4} x_{4}} y_{2}-\frac{\alpha_{20.5} x_{5}}{1+\beta_{20.5} x_{5}} y_{20}
$$

The differential equations of the dynamics of fat and carbohydrate cleavage are formulated in a similar way.

The initial data of the task were the coefficients of enzyme activities and transport mechanisms $\alpha_{1}=0.03, \alpha_{2}=0.01$, $\alpha_{20}=0.001$; the coefficients of the chemical reaction kinetics or substance transfer $\beta_{1}=1, \beta_{2}=1, \beta_{20}=0.01$; the initial protein concentration was $x_{1}=0.1$ (Figure 5).
In the stomach, a decrease in the concentration of the protein substrate $\mathrm{X} 1$ is observed, which is transformed into the denatured form and/or evacuated from the stomach. At the same time, the concentration of denatured protein increases with the further cleavage to peptides X5.

The presented fragment of model realization in the universal simulation model Simplex 3 shows a possibility of virtual study on the influence of different food nutritional value indicators on the rate of digestion and the process of cleavage of complex components to monostructural elements depending on different state and influence factors.

\section{Conclusion}

An advantage of personalized nutrition is indisputable. Nowadays, however, mass production of personalized food products for individuals or small groups of people is unfeasible. The development of personalized food products requires not so much time and labor input as multidisciplinary and profound knowledge in a wide spectrum of areas associated with nutrition, biochemistry, physiology and food technologies. It is necessary to use the system approach with an integrated and detailed examination of a complex food system. The authors made an attempt to bring the theoretical view on an individual product closer to a complex task solution using the method of mathematical physiology. The process of protein cleavage in the form of the IDEF0 scheme is presented. The possibility to simulate the process of protein assimilation in the human stomach is shown in the simulation environment Simplex 3.

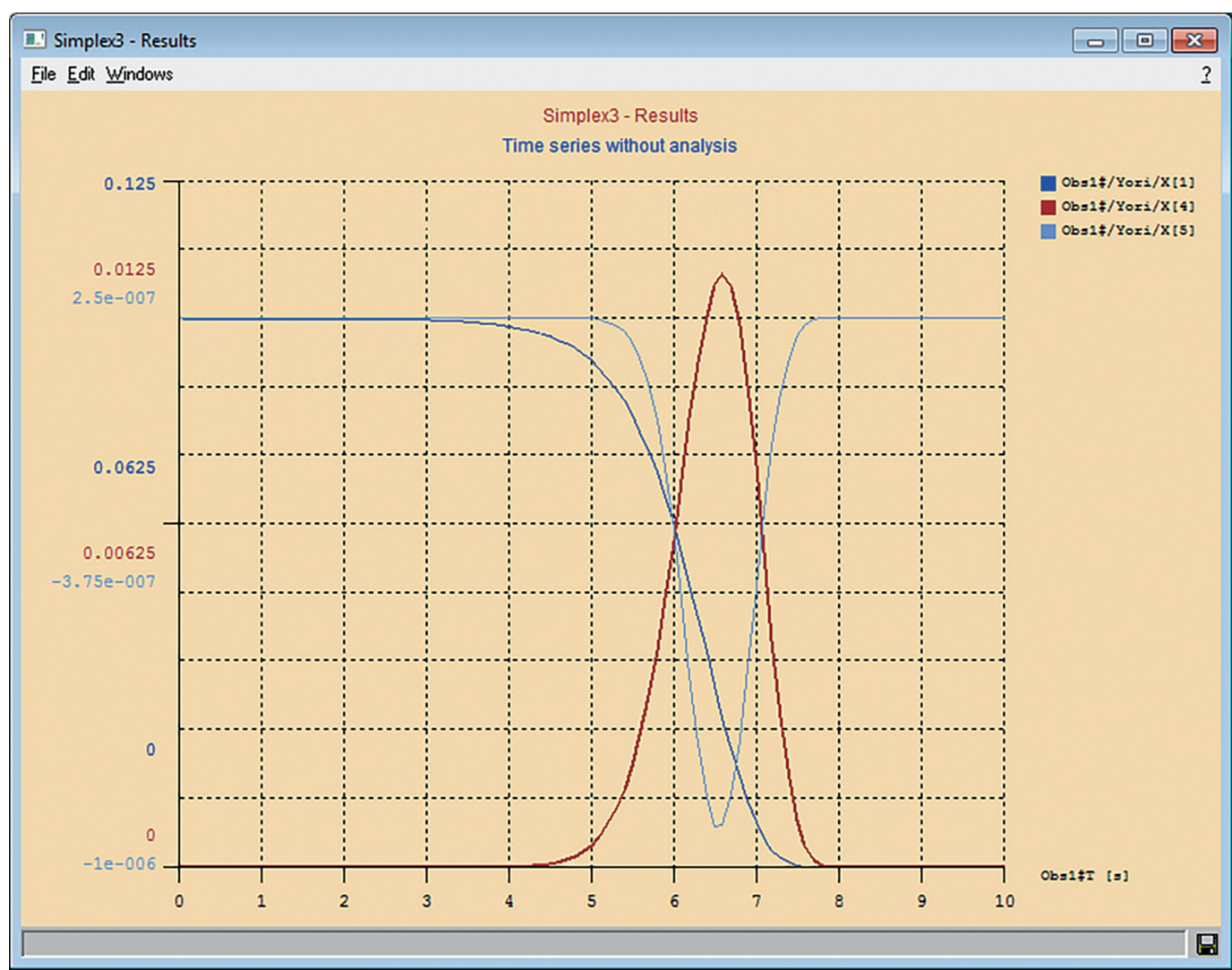

Figure 5. Changes in the concentration of proteins X1, denatured protein $\mathrm{X} 4$, and peptides $\mathrm{X} 5$ in the stomach during the digestive process 


\section{REFERENCES}

1. Williams, R.J. (1956). Biochemical Individuality: The Basis for the Genetotrophic Concept. New York: John Wiley \& Sons. - 272 p. 2. Levy, S., Sutton, G., Ng, P.C., Feuk, L, Halpern, A.L., et al. (2007). The Diploid Genome Sequence of an Individual Human. Plos Biology, 5(10), e254. https://doi.org/10.1371/journal. pbio.0050254

3. Celis-Morales, C., Mathers, J.C., Cibney, M., Walsh, M., et al. (2015). White paper on personalised nutrition - paving a way to better population health. Technical Report. - $101 \mathrm{p}$. https://doi. org/10.13140/RG.2.2.13147.16166

4. EU-funded Food4Me project paves way for personalised nutrition to better public health. Food Today. - 2015. - Vol. 97.

5. Celis-Morales, C., Livingstone, K.M., Marsaux, C.F.M., et al. (2015). Design and baseline characteristics of the Food4Me study: a web-based randomised controlled trial of personalised nutrition in seven European countries. Genes\&Nutrition, 10(1), article number 450. https://doi.org/10.1007/s12263-014-0450-2

6. Franklin, D., Andrews, J. (2012). Megachange: the world in 2050. Hoboken: John Wiley \& Sons. - 320 p. ISBN 1118180445 7. King, T., Cole, M., Farber, J.M., Eisenbrand, G., Zabaras, D., Fox, E.F., Hill, J.P. (2017). Food safety for food security: Relationship between global megatrends and developments in food safety. Trends in Food Science \& Technology, 68, 160-175. https://doi. org/10.1016/j.tifs.2017.08.014

8. Ueland, Ø., Altintzoglou, T., Kirkhus, B., Lindberg, D., Rognså, G.H., Rosnes, J.T., Rud, I., Varela, P. (2020). Perspectives on personalised food. Trends in Food Science \& Technology, 102, 169177. https://doi.org/10.1016/j.tifs.2020.05.021

9. Neeha, V.S., Kinth, P. (2013). Nutrigenomics research: a review. Journal Food Science and Technology, 50(3), 415-428. https://doi.org/10.1007/s13197-012-0775-z

10. Willett, W.C. (2002). Balancing life-style and genomics research for disease prevention. Science, 296(5568), 695-698. https://doi.org/10.1126/science.1071055

11. Chang, A.Y., Skirbekk, V.F., Tyrovolas, S., Kassebaum, N.J., Dieleman, J.L. (2019). Measuring population ageing: an analysis of the Global Burden of Disease Study 2017. The Lancet Public Health, 4, 3, e159-e167. https://doi.org/10.1016/S2468-2667(19)30019-2 12. Socio-demographic Index (SDI) [Electronic resource: http://www.healthdata.org/taxonomy/glossary/socio-demographic-index-sdi. Access date 14.08.2020] (in Russian)
13. von Bertalanffy, L. (1950). The Theory of Open Systems in Physics and Biology. Science, 111(2872), 23-29. https://doi. org/10.1126/science.111.2872.23

14. Sovetov, B. Ya., Yakovlev, S.A. (2017). Systems simulation. Moscow: Yuriat. - 343 p. (in Russian)

15. Buslenko, N.P. (1988). Complex systems simulation. Moscow: Science. -400 p. (in Russian)

16. Vavilov, A.A. (1983). Simulation modeling of production systems. Moscow: Mashinostroenie. - 417 p. (in Russian)

17. Kosturiak, J., Gregor, M. (1995). Simulation von productionssystemen. Berlin: Springer. - 180 p. ISBN 978-3-211-82701-7, https://doi.org/10.1007/978-3-7091-9413-3 (In Germany) 18. Shannon, R.E. (1975). Systems simulation. The art and science. New Jersey: Prentice-Hall. $-387 \mathrm{p}$.

19. Schmidt, B. (2001). The art of modelling and simulation: introduction to the simulation system Simplex3. Ghent.: SCS Europa BVBA. - 500 p. ISBN 3-936150-26-5

20. Ivashkin, Yu.A. (2016). Multi-agent modeling in simulation system Simplex3. Moscow: Knowledge Laboratory - 360 p. ISBN 978-5-906828-72-9 (in Russian)

21. Keener, J., Sneyd, J. Mathematical Physiology. New York: Springer-Verlag. - 547 p. ISBN 978-1-4899-8670-2, https://doi.org/10.1007/978-0-387-75847-3

22. Murray, J. D. (2002). Mathematical Biology. New York: Springer-Verlag. - 551 p. ISBN 978-0-387-95228-4

23. Michaelis, L., Menten, M. L. (1913). Die Kinetik der Invertinwirkung. BiochemischeZeitschrift, 49, 333-369. (In Germany)

24. Lisitsyn, A.B., Chernukha, I.M., Nikitina, M.A. (2019). Development of a personalized meat product using structural-parametric modeling. Theory and practice of meat processing, 4(3), 11-18. https://doi.org/10.21323/2414-438X-2019-4-3-11-18

25. Ivashkin, Yu.A., Nikitina, M.A. (2018). The concept of biological compatibility in optimization of a human diet. Science intensive technologies, 19, 3, 33-45. (in Russian)

26. Ivashkin, Yu.A., Nikitina, M.A. (2017). Multi-agent simulation model of human gastrointestinal tract. Mathematical Methods in Technique and Technologies - MMTT, 5, 77-84. (in Russian)

27. Polenov, S.A., Troitskaya, V.K., Vershinina, E.A. (2003). Regulation of the digestive process: the main mechanisms and their computer simulation. Russian Journal of Gastroenterology, Hepatology, Coloproctology, (Application) 4, 25-29. (in Russian)

\section{AUTHOR INFORMATION}

Andrey B. Lisitsyn - doctor of technical sciences, professor, Academician of the Russian Academy of Sciences, Scientific supervisor, V. M. Gorbatov Federal Research Center for Food Systems of Russian Academy of Sciences. 109316, Moscow, Talalikhina str., 26. Tel: +7-495-676-95-11, E-mail: info@fncps.ru

ORCID: https://orcid.org/0000-0002-4079-6950

Irina M. Chernukha - doctor of technical sciences, professor, Academician of the Russian Academy of Sciences, leading research scientist of Experimental clinic - laboratory «Biologically active substances of an animal origin, V. M. Gorbatov Federal Research Center for Food Systems of Russian Academy of Sciences. 109316, Moscow, Talalikhina str., 26. Tel: +7-495-676-97-18, E-mail: imcher@inbox.ru ORCID: https://orcid.org/0000-0003-4298-0927

Marina A. Nikitina - candidate of technical sciences, docent, leading scientific worker, the Head of the Direction of Information Technologies of the Center of Economic and Analytical Research and Information Technologies, V. M. Gorbatov Federal Research Center for Food Systems of Russian Academy of Sciences. 109316, Moscow, Talalikhina str., 26 Tel: +7-495-676-92-14, E-mail: m.nikitina@fncps.ru

ORCID: https://orcid.org/0000-0002-8313-4105

* corresponding author

All authors bear responsibility for the work and presented data.

All authors made an equal contribution to the work.

The authors were equally involved in writing the manuscript and bear the equal responsibility for plagiarism.

The authors declare no conflict of interest.

Received 09.08.2020 Accepted in revised 15.09.2020 Accepted for publication 25 09.2020 